\title{
Humour and ex-Yugoslav nations: is there any truth in the stereotypes?
}

\author{
Željko Pavić \\ Josip Juraj Strossmayer University of Osijek, Croatia \\ zpavic@ffos.hr
}

\author{
Nataša Krivokapić \\ University of Montenegro in Nikšić, Montenegro \\ natashak@t-com.me
}

\begin{abstract}
This study explores the issue of humour stereotyping between ex-Yugoslav nations, its veridicality and possible explanations. Three research questions were put forward related to humour stereotyping and the differences in humour production, use and appreciation between the countries, with Hofstede's model of culture as a possible explanatory framework. The survey data were collected on a sample of university students from four ex-Yugoslav countries $(N=$ 611). The results revealed strong negative humour stereotyping toward Croats and Slovenians and positive stereotyping toward Bosnians. However, only about 0-4 per cent of the variance in humour production, use and appreciation, depending on the sub-scales of the Multidimensional Sense of Humour Scale, could be attributed to group (country) membership, thus indicating low correspondence between the stereotypes and reality. The study results concerning the stereotypes were interpreted by evoking the discourse of Balkanism, as well as humour-style differences in popular culture between the countries.
\end{abstract}

Keywords: humour stereotypes, multidimensional sense of humour scale, ex-Yugoslavia countries, the Balkans, cross-cultural research.

\section{Introduction: Humour stereotyping among ex-Yugoslav nations}

In the countries of former Yugoslavia (hereinafter: ex-Yu countries) popular ethnic jokes, as well as television and film comedies, have often served as a source and expression of mutual stereotyping. For example, Jontes (2010) demonstrated that ethnic and sexual minorities are represented stereotypically in Slovenian sitcoms, especially when it comes to the alleged stupidity and laziness of Bosnians, thus symbolically marginalising groups that are already socially marginalised. The same can be noted about jokes about Bosnians in Croatia (Marković 2018). Ethnic jokes in socialist Yugoslavia nicely fit into Davies' $(1990 ; 1998 ; 2002 ; 2011)$ 
category of stupidity jokes directed towards peripheral groups in the domain of work as an underlying activity. The butts of stupidity jokes had been ethnic groups from underdeveloped areas, such as Bosnia (Bosnians) and Kosovo (Albanians), while Montenegrins have commonly been labelled as lazy. ${ }^{1}$ Lately, Montenegrins turned the stereotypical jokes to their own advantage by translating the laziness stereotypes about Montenegrins into self-irony-driven mugs, cards, T-shirts and similar products sold to tourists (Koncewicz-Dziduch 2017). On the other hand, Davies' canny jokes directed towards economically overzealous groups had been markedly missing in ex-Yu countries, and still are. In a similar way, the other three activities underlying jokes, that is, sexual behaviour, alcohol consumption and war (Davies 2002), were not translated into ethnic joking, with a possible exemption of jokes that targeted Montenegrin heroism virtues, even though they are by far less present than the laziness jokes targeting them. Genuine ethnic jokes scripts, as Takovski (2018) calls them, which target markers of ethnic identity such as language, national history, clothes, and so on, were probably significantly present only when targeting Albanians as a non-Slavic minority with strained politico-historical relations with some of ex-Yu nations (Serbs, Montenegrins, and North Macedonians).

Such stereotyping is hardly surprising, given the possibility that humour and laughter are essential for social order due to their ability to ridicule various infringements of social values and norms, as Billig (2005) suggested. Bearing in mind the dialectical, social and anti-social nature of humour, it can also be argued that humour stereotyping also serves as a temporary (or permanent) breach of the imperative of mutual respect and political correctness between social groups (Billig 2005: 241-243), even though joking did not closely follow the lines of political conflict in former Yugoslavia. Interestingly, ethnic jokes in socialist Yugoslavia were not publicly scrutinised even though they are usually contested "when jokes target groups other than one's own, with lower social status or with contested social positions" (Kuipers \& van der Ent 2016: 607). A list of explanations might include reluctance to engage in discussions about ethnic relations since, according to the socialist ideology, ethnic conflicts lose their ground in a socialist society, as well as possible political downplaying of the seriousness of the jokes.

However, the ex-Yu situation concerning humour also presents us with an interesting possibility of positive stereotyping of out-groups, and negative self-stereotyping, regarding the supposed ability to produce, use and appreciate humour (hereinafter: humour stereotyping). Even more interestingly, such positive stereotyping of others regarding humour can go hand in hand with the above mentioned negative stereotyping of the same groups in other domains. Some ethnic and geographical groups, especially Bosnians, were positively stereotyped as people who are humorous, hedonistic, relaxed and essentially know how to enjoy life. Jokes about Montenegrins do portray them as lazy, but often also in a well-intended way, underlining their relaxed and laid back character. These positive stereotypes were extended into stereotypes about humorousness as well. According to anecdotal evidence, in Croatia (and also in Slovenia), Serbian and Bosnian humour was, and still is, often perceived as better and more successful than Croatian/Slovene, especially in the field of television and film comedy. In socialist Yugoslavia there was even a kind of competition between television companies, so Zagreb Television often ordered special humorous series (e.g., a TV-series called Naše malo misto [Our little village]) aimed at outdoing the Serbian series, although the perception remained that the Serbian humour was better. In the 1980s, with the radio and TV shows Top lista nadrealista [The Surrealists' Top Chart] and Audicija [Audition], Bosnian films and television humour began to be perceived as superior to Croatian. Thus, today, the second most frequent association connected to Bosnia among Croats and Serbs is "humour and life without stress" (Skoko 2012: 9).

\footnotetext{
${ }^{1}$ This and other observations about joking patterns that follow are not based on a systematic analysis, but they are straightforward and well known to the residents of ex-Yu countries. They can be confirmed by scanning websites with collections of jokes in ex-Yu countries such as www.vicevi.hr, or www.vicevi.net.
} 
The main motivation for conducting the current study is to shed some light on this paradoxical situation. The paper is organised as follows. In the second section of the paper we provide a short overview of hitherto research of cross-cultural differences in humour production, use and appreciation, as well as delineate our research goal and research questions. The third section of the paper is dedicated to detailed explanation of the measurements and sampling employed in the survey study presented in the paper. Section four is divided into two sections. First, we present study results related to mutual humour stereotyping, followed by results of the differences in humour production, use and appreciation. In the fifth section, we compare the two groups of findings and give some theoretical accounts that explain them. We bring the paper to a close by suggesting possible venues of cross-cultural research of humour differences and their theoretical integration with Hofstede et al.'s (2010) model of culture.

\section{Previous research and research questions}

As Martin \& Sullivan (2013) noted, research into the cross-cultural differences in humour production, use and appreciation is not systematic and has hitherto mostly been done by dividing cultures into broad categories of the East and the West. For instance, the findings demonstrate that Westerners value humour more when compared to people from China (e.g., Yue 2010; Yue \& Hiranandani 2014; Yue et al. 2016), and the researchers attribute this difference mainly to Confucian influences and individualism/collectivism as a cultural trait. Similarly, research shows that humour in Japanese culture is more prescribed and restricted to informal situations (for an overview, see Neff \& Rucynski 2017). Likewise, Kuiper et al. (2010) found humour styles differences in terms of their impacts. Namely, research participants from a more collectivist (Lebanese) culture did not respond differently to self-enhancing, affiliative and selfdefeating humour, which was the case for respondents from a more individualistic (Canadian) culture. In other words, Canadians found self-enhancing humour as more beneficial in comparison to the other two humour types (affiliative and self-defeating). Similarly, Lebanese Armenians in Kazarian \& Martin's (2006) research used all four humour styles (affiliative, selfenhancing, aggressive, and self-defeating) from the Humour Styles Questionnaire less than Canadians (Martin et al. 2003) and Belgians (Saroglou \& Scariot 2002). Kalliny et al. (2006) found that American respondents used more self-defeating and self-enhancing humour than Arab ones, whereas there were no differences when it comes to affiliative and aggressive humour, explaining these findings with reference to higher egalitarianism, i.e. lower power distance, present in American culture.

On the other hand, few researchers have addressed the issue of humour differences between culturally more similar countries, even though some preliminary work has been carried out. For example, Martin \& Sullivan (2013) found that the British had negative attitudes towards humorous people when compared to Australians, Americans used more humour in social situations than British respondents, while Americans reported more humour production than Australians. However, they did not offer any theoretical explanations for their findings. Similarly, Ruch \& Forabosco (1996) determined that German respondents more often preferred nonsense humour and less often sexual humour in comparison to Italian ones, hypothesising that the differences might be explained by personality characteristics such as stimulation seeking (the need for uncertain and ambiguous stimuli) and sexual interest (hedonism, disinhibition, etc.) that might be present in different amounts in these cultures.

From this short overview, it can be concluded that there is some research that has tried to identify cross-cultural differences in humour production, use, and appreciation, and to explain their causes. However, theoretical integration of the research is still weak since there is no comprehensive model of the impact of cultural differences on humour, aside from the broad 
East-West classification. However, some research does relate cross-national differences in humour to cultural dimensions according to Hofstede's (1980) model of culture. Geert Hofstede formulated his original model with four dimensions (individualism - IND, masculinity - MAS, uncertainty avoidance - UAI, and power distance - PDI) and the model was subsequently revised on two occasions by supplementing two additional dimensions: long-term versus shortterm orientation - LTI and indulgence versus restraint - IVR (Hofstede 2001; Hofstede et al. 2010). However, the possible connections between these dimensions and cross-cultural differences in humour remain under-researched. Gert Jan Hofstede in his fragmentary overview (2018) delineated possible theoretical connections between cultural values and humour. In his view, cultural values might influence occurrence, style and content of humour. He posited that jokes are more frequently used by individualistic cultures since they more frequently employ context-free communication, while collectivistic cultures would more frequently use word plays and other type of high-context communication. However, we might add that the relation of individualism and humour production, use and appreciation is far from clear. On the one hand, individualistic societies allow conflicting and competitive relations which can be conducive to humour, at least of an aggressive kind. On the other hand, in collectivistic societies people interact socially more often than in individualistic societies, which might imply that humour is used more often as well. According to Gert Jan Hofstede, humour should be less abundant in cultures with a high power distance since humour represents an egalitarian situation where persons from different hierarchical positions can equally participate. As far as masculinity vs. femininity dimension is concerned, while it may be true that his arguments are less than fully clear, Gert Jan Hofstede implies that more masculine societies would use more overstatement in humour, and more sex and gender-related jokes as well. According to him, uncertainty avoidance should be related to taboos with regard to the content of jokes in avoidant cultures, and to joke layering in non-avoidant cultures. We might add here that, in our opinion, uncertainty avoidance also has an uncertain relation to humour. On the one hand, humour can ease the tensions that are present in uncertainty avoidant countries. On the other hand, in most cases humour does play with ambiguities. If we produce and use humour, we certainly risk being misunderstood, and in some cases, this can lead to conflicts and potentially unpleasant or even dangerous situations. Hofstede also suggested that long-term orientation should mainly affect the content of jokes, in the sense that the content reflects long-term or short-term behaviours, i.e. modes of thinking. We should also add here that high indulgence versus restraint (IVR) values should be connected to more frequent production, use and appreciation of humour, since this culture dimension emphasises the very human desires related to enjoying life and having fun.

Research that has tried to connect Hofstede's (1980) culture dimensions and humour differences is still rare. For instance, by partially employing Hofstede's model, Lundquist (2014) found interesting differences between Danish and French humour styles and explained them by the differences in power-distance and hierarchy, developed by long-term historical factors that shaped Danish and French societies. Similarly, as already noted above, Kalliny et al. (2006) explained the differences between Arabs and Americans referring to Hofstede's model, i.e. the difference in power distance. Moreover, as is the case in our study, such research engaged in the comparison of only two or three countries, therefore not being able to generalise the findings in a more rigorous way.

There is also a noteworthy lack of research that deals with humour stereotyping between cultures or nations and their correspondence to some possible real cross-cultural differences. As noted in the previous section, there is numerous anecdotal evidence that there is strong stereotyping between ex-Yu nations with regard to ability to produce, use and appreciate humour. However, up to this point evidence for these perceptions and humour stereotypes has not been thoroughly scientifically investigated. Namely, there is no comparative research into 
the possible real differences in humour production, use and appreciation between these nations. Moreover, as is generally the case, there is no research that deals with the (non)correspondence of humour production, use and appreciation to the above mentioned stereotyping.

The hitherto research on Hofstede's dimension of culture enables us to tentatively compare only Croatia and Serbia since, to our best knowledge, there is no research which would include all four countries. Hofstede's original research (1980) showed that, as expected given the GDP of both countries at the time, Croatia scored lower on PDI, UAI, and scored higher than Serbia on IND (73, 80 and 33 vs 86, 92 and 25). The results on MAS were almost the same (43 vs 40). The differences were replicated in a research on a very small sample conducted by Podrug et al. (2014), albeit the differences between Croatia and Serbia were smaller than in the Hofstede's research. Given that country GDP is negatively correlated with power distance index (PDI) and that this cultural dimension closely corresponds to Ronald Inglehart's (1990) traditional - secular/rational cultural dimension (Hofstede et al. 2010: 78-84), it should be inferred that among the four countries in the sample Croatia should score lowest on PDI, while the differences between the remaining three countries should not be very pronounced. The differences with regards to uncertainty avoidance indices, being positively correlated with GDP, should follow the same logic. As already reported, in the original Hofstede's data, Serbia and Croatia had pretty similar values on masculinity index (Hofstede 1980). Having in mind that masculinity index is not correlated with GDP (Hofstede et al. 2010: 140), the direction and strength of differences in MAS between the four countries cannot be theoretically predicted. When it comes to long-term orientation (LTI) and indulgence versus restraint (IVR), there is no research comparing the four countries by employing some of the Hofstede's measurements. However, Hofstede et al. (2010: 255-258) calculated LTI and IVR based on items from World Value Survey (WVS) that bear some conceptual resemblance to LTI. As it turned out, Montenegro and Bosnia and Hercegovina (75 and 70, respectively) had somewhat higher scores on LTI than Croatia and Serbia (58 and 52, respectively), while Croatia and Serbia (33 and 28, respectively) had somewhat higher results on IVR than Montenegro (20). Nevertheless, we should sound a note of caution with regard to these scores since they only represent far from perfect approximations of true LTI and IVR scores.

The main research goal of this paper is, therefore, to investigate the extent of the differences in humour production, use and appreciation, on the one side, and humour stereotyping between four ex-Yu nations (Bosnians/Herzegovinians, Croats, Montenegrins, Serbs) on the other side, as well as the extent to which the assumed differences are veridical. Bearing in mind somewhat unclear theoretical connections between Hofstede's dimensions of culture and humour use, production and appreciation, in our study we could not have proposed specific hypotheses. Instead, the study was an explorative one, and three research questions have been put forward:

RQ1. Is there mutual humour stereotyping among four ex-Yu countries (Bosnia and Herzegovina, Croatia, Montenegro, Serbia) concerning humour production, use and appreciation?

RQ2. Do these stereotypes reflect the real differences in humour production, use and appreciation between the countries?

RQ3. Can the differences in humour production, use and appreciation be explained through cultural differences between the aforementioned countries as measured by the Hofstede's model of culture? 


\section{Methods}

\subsection{Measurements}

There is a widespread agreement that humour is a complex, multidimensional social phenomenon (e.g., Robinson \& Smith-Lovin 2001; Lockyer \& Pickering 2008; Inglis et al. 2014). Its content ranges from humour creativity and production, humour appreciation, comprehension and enjoyment, humour expression, use of humour in everyday social situations, use of humour for coping, etc. Given the nature of the construct, it is no surprise that various humour scales have been proposed that tap into different components of humour.

In the current study, perception of humour production, use and appreciation, i.e. humour stereotyping, among the ex-Yu nations was measured by employing two single-item questions. More precisely, respondents were asked to indicate on a five-point scale how funny average members of the ex-Yu nations (Bosnians, Croats, Montenegrins, North Macedonians, Slovenians, and Serbs ${ }^{2}$ ) are, and how much they appreciate humour. The exact phrases were: "How funny/able to produce humour/make jokes is an average member of the following nations?" and "To what extent is an average member of the following nations able to appreciate humour?" If they had never met any of the members of the selected nations, which is a reasonable assumption given that the sample consisted of university students, the respondents were supposed to indicate their expectation about the humorousness and humour appreciation of the average member of a nation (i.e., to express their humour stereotypes).

When it comes to self-report measures of humour production, appreciation and use, as one of the most common measurement types, there are also several more or less validated questionnaires. Some of them are Sense of Humour Questionnaire - SHQ (Svebak 1974; 1996; 2010), Situational Humour Response Questionnaire - SHQR (Martin \& Lefcourt 1984) and Humour Styles Questionnaire - HSQ (Martin et al. 2003). Bearing in mind that our research goal is to explore the humour stereotypes between ex-Yu nations and that these stereotypes are mainly related to the humour production, use and appreciation, we have chosen to employ the so-called Multidimensional Sense of Humour Scale - MSHS, created by Thorson \& Powell (1993a). In the original study, the scale had four components - social production and use of humour, adaptive humour, appreciation of humour, and attitudes toward humour, that are, in our view, a good conceptual match to the content of the afore-mentioned humour stereotypes. The scale was subsequently validated on several instances and in different countries (Thorson \& Powell 1993b; Carbelo-Baquero et al. 2006; Ho et al. 2008; Boyle \& Joss-Reid 2010; Sousa et al. 2018), granted that the number of extracted dimensions somewhat varied across studies. In the current study, we carried out a factor analysis on the 24 scale items, with respondents indicating item endorsement using a five-point Likert scale with anchors $1=$ strongly disagree and $5=$ strongly agree, to determine the dimensionality of the scale. Prior to the analysis, we made sure that our data were well suited for factor analysis - the Keiser-Meyer-Olkin measure of sampling adequacy amounted to a satisfying 0.91, while Bartlett's sphericity test was statistically significant. With the maximum likelihood as the extraction method and varimax rotation of the initial solution, we obtained a four-factor solution with the afore-mentioned factors/components. ${ }^{3}$ Confirmatory factor analysis on a separate sample of university students

\footnotetext{
${ }^{2}$ Even though our sample did not include respondents from Slovenia and North Macedonia, we had included them as possible targets of humour stereotyping in order to complete the picture for all six ex-Yu nations.

${ }^{3}$ There were slight differences in factor structure between the current study and Thorson \& Powell (1993a; 1993b). Namely, the item "I can use wit to help adapt to many situations" in the current study had high factor loadings on both Humour production and social uses of humour and Adaptive humour sub-scales (factor loadings were .53 and .42 , respectively). The item "Uses of humour help to put me at ease" is significantly loaded on the
} 
from Croatia $(\mathrm{N}=100)$ lent support to such dimensionality of the scale. Therefore, we summed up results on items that were heavily loaded on specific sub-scales in order to obtain summary results for the sub-scales. Negatively-worded items were reversed before summation. As a result, the Social production and use of humour sub-scale consisted of 12 items (items no. 1-11 and 18 from Thorson \& Powell 1993a: 21), the Adaptive humour sub-scale consisted of six items (items no. 12-17), the Humour appreciation sub-scale of two items (items no. 19 and 20), and the (negative) Attitudes towards humour sub-scale comprised four items (items no. 21-24). Cronbach's alphas for the sub-scales were as follows: $0.91,0.84,0.67$, and 0.77 , reflecting the intercorrelation and number of items in the sub-scales.

In the current study, we also employed the Value Survey Module 2013 (Hofstede \& Minkov 2018), namely the latest questionnaire developed by Hofstede and his associates. The questionnaire contains 30 questions in total, 24 content questions and 6 demographic questions. Given the nature of our sample (university students), we omitted three demographic questions in our research - age, education level and job type - since they would not provide enough variation for analytic purposes. VSM 2013 contains six dimensions of culture, one more than VSM 94, and two more than VSM 82 - the initial version of the questionnaire. The four initial dimensions - individualism-collectivism (IDV), masculinity-femininity (MAS), uncertainty avoidance (UAI) and power distance (PDI), were amended by long-term versus short-term orientation (LTO; introduced in VSM 94), and indulgence versus restraint (IVR, introduced in VSM 2013). The first revision followed from the analysis of the so-called Chinese Values Survey (Hofstede \& Bond 1988), while the second resulted from the analysis of the World Value Survey data, performed by Michael Minkov (2007).

\subsection{Sampling}

We used a sample consisting of students from four Faculties of Humanities and Social Sciences ${ }^{4}$ in Bosnia and Herzegovina (University of Tuzla), Croatia (Josip Juraj Strossmayer University of Osijek), Montenegro (University of Montenegro) and Serbia (University of Niš). Even though students represent a specific social group that cannot be taken as representative of a society as a whole, we can assume that they are somewhat exposed to humour stereotyping between the exYu nations included in the sample. Due to the mutually understandable languages, students do travel to other ex-Yu countries and consume their popular culture products as well.

The student groups for conducting the survey were randomly selected from a list of groups/study programmes. The sample comprised a total of 611 respondents/undergraduate and graduate students, with similar numbers across countries (Croatia - 154, Bosnia and Herzegovina - 157, Montenegro - 150 and Serbia - 150). The share of female students was 73.0 per cent, which was expected since faculties of humanities and social sciences enrol significantly more female than male students. The data were collected from January to April 2019 by means of self-administered surveys during the classes, wherein the average length of the survey completion was about ten minutes. The questionnaires were administered in local languages (Bosnian, Croatian, Montenegrin and Serbian), while the equivalence of the questionnaires was ensured by back-translating the local versions from the English original. Additionally, it has to be borne in mind that the differences between the above-mentioned local languages are not substantial, and the authors, who have good command of all of them, made sure that they are accounted for in the questionnaires. The research was approved by the Ethical Committee of the Faculty of Humanities and Social Sciences in Osijek.

Adaptive humour and Humour appreciation sub-scales (.44 and .36), but this was also the case in Thorson \& Powell (1993a).

${ }^{4}$ In all four languages, these faculties are called filozofski fakultet, meaning 'faculties of philosophy'. However, they enrol students from various disciplines in humanities and social sciences. 


\section{Results}

\subsection{Humour stereotyping}

The first set of analyses investigated humour production stereotyping. It can be concluded from Table 1 that there is a pronounced East-West division, wherein Croats and Slovenes are judged as substantially less funny (the average results are 2.95 and 2.79 , respectively), with North Macedonians (3.02), somewhat surprisingly, being closer to them than to Bosnians/Herzegovinians, Montenegrins and Serbs (4.15, 3.74 and 3.68, respectively). By observing confidence intervals of the means, we can conclude that Slovenes are the lowest rated, Croats and North Macedonians represent the second, and Serbs and Montenegrins the third group. Bosnians and Herzegovinians are rated highest in this regard. We should restate here that we included Slovenes and North Macedonians as attitude objects, even though, due to resources limitations, we were not able to carry out research there as well. It should be noted that Table 1 represents "an external view," i.e. it does not include opinions about one's own nation.

Table 1. Perception and self-perception of humorousness/humour production (“funny, able to produce humour and make jokes")

\begin{tabular}{|l|l|l|l|l|l|l|}
\hline & \multicolumn{5}{l|}{ Perception } & \multicolumn{2}{l|}{ Self-perception } \\
\hline Nation & $\begin{array}{l}\text { Mean } \\
(1-5)\end{array}$ & St. dev. & $95 \%$ CI & $\begin{array}{l}\text { Mean } \\
(1-5)\end{array}$ & St. dev. & $95 \%$ CI \\
\hline Croats & 2.95 & 1.20 & $2.84-3.06$ & 3.71 & 0.80 & $3.58-3.84$ \\
\hline Serbs & 3.68 & 1.08 & $3.58-3.78$ & 4.22 & 0.90 & $4.08-4.36$ \\
\hline Montenegrins & 3.74 & 1.05 & $3.65-3.84$ & 4.43 & 0.93 & $4.28-4.58$ \\
\hline $\begin{array}{l}\text { Bosnians and } \\
\text { Herzegovinians }\end{array}$ & 4.15 & 1.10 & $4.05-4.25$ & 4.40 & 0.86 & $4.26-4.53$ \\
\hline Slovenians & 2.79 & 1.05 & $2.70-2.87$ & N/A & N/A & N/A \\
\hline $\begin{array}{l}\text { North } \\
\text { Macedonians }\end{array}$ & 3.02 & 1.08 & $2.94-3.11$ & N/A & N/A & N/A \\
\hline
\end{tabular}

Note: Means listed in column 2 exclude perceptions about humorousness/humour production of the average member of one's own nation.

When looking at confidence intervals in Table 1, we can conclude that Croats do not express very high level of positive outlook when it comes to their humour production, at least when compared to other three nations. Moreover, it is interesting to note that only Croats do not judge themselves as more apt than the other nations in terms of the ability to produce humour. To be more precise, Croats judge Bosnians/Herzegovinians as funnier than themselves (3.71 vs. 4.58), while they judge Serbs and Montenegrins as equally funny as themselves (3.80 and 3.75, respectively). They only judge Slovenes and North Macedonians to be less funny than themselves (3.71 vs 2.68 and 3.05, respectively). In contrast, Bosnians/Herzegovinians, Montenegrins and Serbs judge themselves to be funnier and more humour appreciative when compared to their opinion about other nations. It can also be noted that in all these cases positive self-stereotyping was found, i.e. that all nations have much higher opinion about themselves 
when compared to the opinion of others about them. The only exception is the opinion of Croats towards humorousness and humour appreciation of Bosnians/Herzegovinians that is even more positive when compared to opinions of the Bosnians/Herzegovinians towards themselves (4.58 vs. 4.40, and 4.51 vs 4.31, respectively). Additionally, when inspecting Table 1, it is interesting to note that that the difference between self-perception and the opinion of others is quite high among Croats (0.76), Montenegrins (0.69), and Serbs (0.57), while being much lower among Bosnians/Herzegovinians (0.25).

The stereotypes are pretty similar when it comes to humour appreciation (Table 2). Specifically, the ranking among the nations stays the same, with Bosnians/Herzegovinians ranked as the most humour appreciative (4.08), followed by Serbs (3.76) and Montenegrins (3.75). North Macedonians (3.20) and, especially, Croats and Slovenians (both 2.98), are rated significantly lower in this regard. When looking at the confidence intervals, the only difference in comparison to Table 1 is a slightly changed grouping, with Croats being more similar to Slovenes, while both being slightly lower ranked than North Macedonians.

Table 2. Humour appreciation perception and self-perception ("understands and appreciates humour and jokes")

\begin{tabular}{|l|l|l|l|l|l|l|}
\hline & \multicolumn{5}{l|}{ Perception } & \multicolumn{3}{l|}{ Self-perception } \\
\hline Nation & $\begin{array}{l}\text { Mean } \\
(1-5)\end{array}$ & St. dev. & $95 \%$ CI & $\begin{array}{l}\text { Mean } \\
(1-5)\end{array}$ & St. dev. & $95 \%$ CI \\
\hline Croats & 2.98 & 1.19 & $2.88-3.09$ & 3.79 & 0.80 & $3.65-3.93$ \\
\hline Serbs & 3.76 & 1.04 & $3.67-3.86$ & 4.12 & 0.98 & $3.96-4.28$ \\
\hline Montenegrins & 3.75 & 1.03 & $3.66-3.85$ & 4.29 & 1.01 & $4.13-4.46$ \\
\hline $\begin{array}{l}\text { Bosnians and } \\
\text { Herzegovinians }\end{array}$ & 4.08 & 1.11 & $3.98-4.18$ & 4.31 & 0.91 & $4.16-4.45$ \\
\hline Slovenians & 2.98 & 1.05 & $2.89-3.06$ & N/A & N/A & N/A \\
\hline $\begin{array}{l}\text { North } \\
\text { Macedonians }\end{array}$ & 3.20 & 1.05 & $3.12-3.28$ & N/A & N/A & N/A \\
\hline
\end{tabular}

Note: Means listed in column 2 exclude perceptions about humour appreciation of the average member of one's own nation.

As in the case of humour production, Croats are the only ones who do not think that their own ability of humour appreciation is better than that of the each other nation. More precisely, the Croatian respondents rated Croatian humour appreciation with the average of 3.79, which is similar as their rating of Serbs (3.87) and Montenegrins (3.81), being highly inferior to their rating of Bosnians/Herzegovinians (4.51). Only Slovenes and North Macedonians are judged less humour appreciative (2.97 and 3.27, respectively). Here as well we can find pronounced differences between self-perception and the opinions of others, the highest among Croats $(0.81)$, followed by Montenegrins (0.54), Serbs (0.36), and Bosnians/Herzegovinians (0.23). In other words, all of these nations perceive themselves as much more humour appreciative in comparison to the opinion of other nations in this regard. 


\subsection{Group differences in humour production, use and appreciation}

In Table 3, the results on the humour sub-scales for each country as well as ANOVA results are presented. Notwithstanding the fact that the differences are statistically significant in the cases of the two sub-scales (humour production and social uses of humour, humour appreciation), the effects are small and non-consistent. Namely, post-hoc ANOVA revealed that Croatian students indeed tend to produce less humour when compared to their counterparts from Montenegro and Bosnia and Herzegovina, but are at the same time more appreciative of humour than Montenegrins and do not differ in this regard from Serbs and Bosnians and Herzegovinians. Similarly, the respondents from Montenegro showed lower level of humour appreciation when compared to the respondents from the other countries.

Table 3. ANOVA on sub-scales of the Multidimensional Sense of Humour Scale between the nations

\begin{tabular}{|l|l|l|l|l|}
\hline Nation & $\begin{array}{l}\text { Social production } \\
\text { and use of humour }\end{array}$ & $\begin{array}{l}\text { Adaptive } \\
\text { humour }\end{array}$ & $\begin{array}{l}\text { Humour } \\
\text { appreciation }\end{array}$ & $\begin{array}{l}\text { Negative attitudes } \\
\text { towards humour }\end{array}$ \\
\hline $\begin{array}{l}\text { Bosnians and } \\
\text { Herzegovinians }\end{array}$ & 43.46 & 27.54 & 9.24 & 6.85 \\
\hline Croats & 41.14 & 27.02 & 9.33 & 7.10 \\
\hline Montenegrins & 44.18 & 26.15 & 8.74 & 7.23 \\
\hline Serbs & 42.95 & 26.90 & 9.21 & 7.20 \\
\hline & $\mathrm{F}=4.24 ; \mathrm{p}=0.01$ & $\begin{array}{l}\mathrm{F}=2.27 ; \\
\mathrm{p}=0.08\end{array}$ & $\begin{array}{l}\mathrm{F}=7.75 ; \\
\mathrm{p}=0.00\end{array}$ & $\mathrm{~F}=0.62 ; \mathrm{p}=0.60$ \\
\hline
\end{tabular}

We then proceeded with a variance components multi-level regression aimed at exploring the amount of variation that can be attributed to the group level (country differences). In other words, we set up the so-called null model with no predictors and a random intercept. The single equation of the null model can be written as follows:

$$
Y_{i j}=\gamma_{00}+u_{0 j}+\varepsilon_{i j}
$$

wherein $\gamma_{00}$ represents the intercept, $u_{0 j}$ variation in country intercepts and $\varepsilon_{i j}$ variation in individual scores (error variance).

Since the intercepts represent just a weighted averages of the country results on the subscales already presented in Table 3, we proceed with the estimates of the variance components (intercept variance and residual/error variance) for all four criterion variables. The results are reported in Table 4, with restricted maximum likelihood (REML) chosen as the estimation method. Here we should note that the intercept variances are small and that they do not significantly differ from zero. In other words, level 2 (country) differences in the sub-scales results are non-existing, and in the case of negative attitudes towards humour the differences are so small that the intercept variance could not be mathematically estimated. 
Table 4. Variance components of the null multilevel model

\begin{tabular}{|c|c|c|c|c|}
\hline Sub-scale & Estimate & Std. error & Wald Z & Sig. \\
\hline \multicolumn{5}{|l|}{ Social production and use of humour } \\
\hline Intercept variance & 0.87 & 0.90 & 0.97 & 0.33 \\
\hline Residual & 60.81 & 3.49 & 17.42 & 0.00 \\
\hline \multicolumn{5}{|l|}{ Adaptive humour } \\
\hline Intercept variance & 0.19 & 0.27 & 0.69 & 0.49 \\
\hline Residual & 22.30 & 1.28 & 17.42 & 0.00 \\
\hline \multicolumn{5}{|l|}{ Humour appreciation } \\
\hline Intercept variance & 0.06 & 0.08 & 1.07 & 0.29 \\
\hline Residual & 1.38 & 0.06 & 17.42 & 0.00 \\
\hline \multicolumn{5}{|l|}{ Negative attitudes towards humour } \\
\hline Intercept variance & - & - & - & - \\
\hline Residual & 7.31 & 0.42 & 17.46 & 0.00 \\
\hline
\end{tabular}

The intraclass correlation (ICC) can be calculated as $\rho=\frac{\sigma_{B}^{2}}{\sigma_{B}^{2}+\sigma_{W}^{2}}$, i.e. as the quotient of betweengroups and total variance. From Table 5 it can be ascertained that the between-groups variance is very small when compared to the total variance, i.e., that group differences account for 1-4\% of the total variance (even less when it comes to negative attitudes towards humour).

Table 5. Intraclass correlation coefficients (ICC) of the MSHS sub-scales

\begin{tabular}{|l|l|}
\hline Sub-scale & ICC \\
\hline Social production and use of humour & 0.01 \\
\hline Adaptive humour & 0.01 \\
\hline Humour appreciation & 0.04 \\
\hline Negative attitudes towards humour & Cannot be estimated \\
\hline
\end{tabular}

In order to explore RQ3, we calculated the average scores on six cultural dimensions according to the Hofstede's model. The results presented in Table 6 show that there are differences in the Power Distance index and Long-Term Orientation, while the differences on the other four dimensions are less pronounced. Specifically, power distance is highest in Montenegro and lowest in Serbia, while long-term orientation is highest in Bosnia and Herzegovina and lowest in Montenegro. However, since there were no significant differences in humour production, use and appreciation between the countries, there was no point in trying to connect them to Hofstede's model. 
Table 6 . Average scores on culture dimensions by countries

\begin{tabular}{|l|l|l|l|l|l|l|}
\hline Country & PDI & UAI & IDV & MAS & LTO & IVR \\
\hline $\begin{array}{l}\text { Bosnia and } \\
\text { Herzegovina }\end{array}$ & 67.60 & 66.10 & 70.45 & 68.20 & 71.65 & 64.80 \\
\hline Croatia & 58.05 & 57.40 & 78.85 & 74.15 & 59.00 & 67.50 \\
\hline Montenegro & 72.60 & 66.30 & 65.90 & 75.20 & 50.70 & 60.35 \\
\hline Serbia & 32.55 & 62.05 & 68.35 & 70.30 & 60.90 & 69.70 \\
\hline
\end{tabular}

\section{Discussion and conclusions}

According to the Stereotype Content Model (Glick \& Fiske 1999; Fiske et al. 1999; 2002), there are two clusters of stereotypes: stereotypes about competence (intelligent, diligent, hardworking, ambitious, etc.) and stereotypes about warmth (warm, good-natured, tolerant, sincere, etc.). Both clusters include traits and their opposites that can denote both negative and positive stereotyping. A number of studies (e.g., Leach et al. 2007; Brambilla et al. 2011; 2013) found that the warmth cluster can be further divided into morality (honest, sincere, peaceful, etc.) and sociability (cheerful, friendly, kind, likeable, etc.) clusters. Using this model as a classification device, we can conclude that the scarce and incomplete research about overall stereotyping between ex-Yu nations ${ }^{5}$ (Petrović 2003; Skoko 2010; 2012) showed high levels of mutual negative stereotyping concerning morality, especially when it comes to the stereotypes between Bosniaks, Croats and Serbs. Economically more advanced nations (such as Croats and Slovenes) are, to a degree, perceived as competent, but also as nations lacking warmth. Since the researchers used methods of free associations (Skoko 2010; 2012) and forced choices of five traits that are the best representation of a nation (Petrovic 2003) the result was a great number of negative stereotypes mainly concerning morality (not surprisingly, given the recent armed conflicts between the countries). We are, therefore, not able to precisely infer the content of mutual humour stereotyping from the afore-mentioned studies and to compare it with our results. Namely, humour was rarely listed by the respondents as a trait that is characteristic for members of the ex-Yu nations, and even then exclusively when evaluating people from Bosnia and Herzegovina.

The results from the current study showed the humour stereotyping among students from the selected ex-Yu nations, which was somewhat predictable in the light of anecdotal evidence and the afore-mentioned research on overall stereotyping, thus affirmatively answering our RQ1. The stereotypes follow the East-West line, i.e. the supposed geographical and cultural border between the Balkans and Central Europe.

We offer two kinds of explanations for the observed differences: one stems from the cultural anthropology and imagology, and the other from popular culture differences. First, we can note that the stereotypes that we found in the study follow the East/West divide, with the exception of Macedonia, which was even closer to the Western countries (Croatia and Slovenia) than to the geographically closer Serbia, Montenegro, and Bosnia and Herzegovina. Such

${ }^{5}$ In his study, Petrović (2003) used a sample of university students which included only Croats, Bosniaks and Serbs, while Skoko used a sample of general population in Serbia and Croatia when it came to the research of the attitudes towards the people from Bosnia and Herzegovina (Skoko 2012) and samples of general population of Bosnia and Herzegovina, Macedonia, Montenegro, Serbia and Slovenia in case of the research which mainly dealt with stereotypes about Croats (Skoko 2010). 
stereotyping might be attributed to the long-term stereotyping that forms a part of the discourse of Balkanism (Todorova 2009), which translated into internal discourses of Balkanism that produce cycles of stereotyping and self-stereotyping. As an illustration of such internal discourse in Croatia, British novelist Rebecca West noted in her famous travelogue Black Lamb and Grey Falcon (1946 - written mostly in 1941) that Croats try to dissociate themselves from the Balkans and show their closeness to the Western culture: "We are not as the Serbs in Belgrade, here we are business-like, we do things as they are done in Vienna" (West 1946: 90). As Luketic (2013) noted, such dissociation from the Balkans as a violent and primitive geographical and cultural space is vividly present in post-socialist Croatia. On the other hand, she continued, both from the inside and from the outside, the Balkans are also positively imagined as a space of hedonism, emotionality, and joie de vivre (humour included). Thus, there is a form of auto-orientalism where the Balkans are inscribed with some laudable characteristics that the developed West has supposedly lost (Luketić 2013). This discourse probably dates back to the so-called Zenitism avant-garde artistic (mainly literary) movement in 1920's in Yugoslavia that created a symbolic figure of the Barbarogenius, i.e. Balkanic artist that can revive Europe with his elementary, authentic and vibrant strength and wildness, as opposed to European rationalism and "softness." This movement was the first one to reverse the position between the Balkans and Europe, thus inscribing the Balkans with a superior, utopian role (Đergović-Joksimović 2015). The traces of the positive side of Balkanism discourse can be found in contemporary ex-Yu artistic works, such as in Emir Kusturica's films and Branimir Štulić's music. For instance, Kusturica's famous film Underground can be observed through the lenses of Balkanism discourse since it espouses "poetics of excess," i.e. the emotionality, spontaneity and frenzy ascribed to the Balkans (Slugan 2011). Humour is a part of such "excess" and spontaneity; it is one of the key characteristics that supposedly make the Balkans different when compared to the "serious" and "boring" West. However, there is no research that could reveal which one of these opposing sides of Balkanism is more often present in public opinion of ex-Yu countries.

Secondly, humour stereotyping might even be related to popular culture development in socialist Yugoslavia. For example, granted that there were no scientific research at the time dealing with the issue of national stereotyping with relation to humour, it seems that the high esteem of the "Bosnian humour" among the other nations in the former Yugoslavia started in the 1980's with the so-called New Primitives pop culture movement, especially with its most significant component - the comedy TV-series Top lista nadrealista [The Surrealists' Top Chart]. Both the movement and the TV-series developed within the framework of youth culture that arose within the institutional system of the League of Socialist Youth, but transcended the official youth culture by advocating cosmopolitanism, democratic spirit, freedom of speech and freedom in general (for a detailed analysis, see Spaskovska 2017). Thus, there might be a kind of divergence between Croatian popular culture comedy and the audience tastes, especially in the young audience. We are of the opinion that the differences between Croatian popular culture comedy, on the one hand, and Bosnian/Serbian/Montenegrin comedy, on the other, are akin to the wide-ranging differences between the Dutch and American humour styles determined in Kuipers' (2015) research. Namely, Croatian television and film humour is less edgy and transgressive than the humour of the afore-mentioned nations, with more frequently present moral and sociability overtones. For instance, we posit that Serbian comedy films and TV-series are highly appreciated in Croatia precisely due to their often vulgar, shocking and sarcastic humour style which can be rarely observed in Croatian comedies that are more frequently "goodnatured" and try to offer a positive outlook on bad things in life. Since Kuipers confirmed that humour styles are age-related as well, the nature of our sample that consisted of university students might also have produced such research results. However, future research should investigate whether there is such divergence between the Croatian (and possibly Slovenian) 
popular culture and popular comedy taste, and whether this phenomenon is age-related. Additionally, such divergence could be explained by the above-mentioned discourse of Balkanism and the persisting attempt of the Croatian cultural nationalists to dissociate Croatia and Croatian culture from the Balkans and the other ex-Yu nations.

Judging from the results of humour production/use/appreciation, the aforementioned stereotypes are not reality-based. Namely, the country differences account for only about 0-4 per cent (depending on a sub-scale) of the variability among respondents. A further elaboration is warranted here. Firstly, can we rely on self-perception relating to humour, i.e. do MSHS and other self-report based measurement scales represent valid instruments for measuring sense of humour? Given that the sense of humour is a positive social trait, it can be assumed that persons would elevate their self-perception of this trait in order to preserve self-respect. In spite of some earlier research (Lefcourt \& Martin 1986; Kruger \& Dunning 1999) showing that people are not the best judges of their own sense of humour, more recent research indicates nomological validity of self-perception of humour and MSHS. Namely, Cann \& Calhoun (2001) determine that hypothetical others with varying sense of humour are related to specific personality and social traits in the respondents' minds. Building on this research, Beins \& O'Toole (2010) find a correlation between the results on MSHS and subjective (one-item) measurement of sense of humour, as well as a correlation between self-attributed personality traits and both measures of sense of humour. Be that as it may, we have no prior reason to believe that members of some ex-Yu nations are more prone to error in the evaluation of one's own sense of humour than the others. Secondly, sense of humour might be a relative thing. To be more specific, self-perception might be related to the average level of sense of humour in a society. To put it bluntly, a less funny person might appear as more funny in a society with a lower average sense of humour level, thereby raising the score on the sense of humour scale. However, when inspecting MSHS it can be noted that only the first sub-scale - humour production - might be affected by this effect, and even then, this goes only for a few scale items. For instance, the item "People look to me to say amusing things" might imply a different level of humour production in different societies. Having all this in mind, we can conclude that the answer to RQ2 is that stereotyping concerning humour among ex-Yu nations does not reflect any real and substantial differences in humour production, use and appreciation that would be congruent with the stereotypes. It seems that in this case indeed there is not much truth in stereotypes.

Given that there were no significant differences between the countries in humour production, use and appreciation, we could not reference Hofstede et al.'s (2010) cultural dimensions while attempting to explain study results. Even if the differences had existed, as in the previous research that employed this model, we could have used the model only as a preliminary explanation. More specifically, in the current study we could not reliably proceed with multi-level modelling with Hofstede's dimensions as level 2 predictors, i.e. this was not a part of our research plan, since our sample consisted of respondents from only four countries, which is not a sufficient sample size for multilevel-modelling (Bickel 2007; Heck et al. 2010). In that sense, our results would have been only of exploratory nature. However, even though we could not reliably test whether Hofstede et al.'s (2010)) model of culture can elucidate differences in humour production, use and appreciation, we think that it might provide a theoretical model that could be checked in future research that would comprise multi-national samples coming from large number of different and humour-diverging cultures. Comparison of our results with Hofstede et al.'s (2010) results point to the same direction, i.e. relative consistency between the results indicates that Hofstede et al.'s (2010) cultural dimensions show some temporal stability. Namely, although original Hofstede et al.'s (2010) sample (IBM employees) and our sample (university students) are completely different, relative position of Croatia and Serbia on IND and UAI is the same, while positions of Bosnia and Herzegovina and Montenegro are congruent with theoretical expectations. Relative positions on PDI are 
congruent with the theory, with Serbian low PDI in our study as unusual exception. The difference between Croatia and Serbia on MAS is small, both in our study and in Hofstede et al.'s (2010) data, while the theory does not predict positions of the other two countries. Relative positioning on IVR is the same in both studies, while only Montenegro's position on LTI is discordant.

In our view, the main limitation of the current study lies in its sample structure. Namely, it has to be noted that the matched samples strategy assumes that the differences concerning cultural dimensions are similar across all kinds of social strata and social groups, i.e. that eliminating sources of variation enables us to determine cultural differences in a more precise way. However, a word of caution is warranted. It is possible that some social strata and groups share similarities that extend beyond cultural differences, i.e. that their value similarities might overpower possible differences in national culture. In our case, a student of social sciences and humanities might be very similar in cultural orientations, which would exert important consequences on our results by not allowing us to detect a possible impact of culture on humour differences. The other possible limitation also arises from the sample structure, this time from its geographical scope. Namely, we chose four faculties from one region from each of the participating country. However, this entails a possibility of not accounting for regional humour differences. These differences have not been researched at all, but some anecdotal evidence suggest that they might exist in some of the countries. For instance, the Croatian region of Dalmatia is usually labelled as a region with people who extensively draw on humour in everyday situations.

\section{Acknowledgements}

The authors would like to express their gratitude to the management, teachers and students of the participating faculties for their assistance in data-collection. We are particularly grateful to Centre for Research in Social Work and Social Policy, Faculty of Humanities and Social Sciences, University of Niš (Serbia).

\section{References}

Beins, B. C. \& O'Toole, S. M. (2010). 'Searching for the sense of humor: Stereotypes of ourselves and others'. Europe's Journal of Psychology 3, pp. 267-287.

Bickel, R. (2007). Multilevel Analysis for Applied Research. It's Just Regression! New York: Guilford Press.

Billig, M. (2005). Laughter and Ridicule. Towards a Social Critique of Humour. London: Sage Publications.

Boyle, G. J. \& Joss-Reid, J. M. (2010). 'Relationship of humour to health: A psychometric investigation'. British Journal of Health Psychology 9(1), pp. 51-66.

Brambilla, M., Rusconi, P., Sacchi, S. \& Cherubini, P. (2011). 'Looking for honesty: The primary role of morality (vs. sociability and competence) in information gathering'. European Journal of Social Psychology 41(2), pp. 135-143.

Brambilla, M., Sacchi, S., Pagliaro, S. \& Ellemers, N. (2013). 'Morality and intergroup relations: Threats to safety and group image predict the desire to interact with outgroup and ingroup members'. Journal of Experimental Social Psychology 49, pp. 811-821.

Cann, A. \& Calhoun, L. G. (2001). 'Perceived personality associations with differences in sense of humor: Stereotypes of hypothetical others with high or low senses of humor'. HUMOR: International Journal of Humor Research 14(2), pp. 117-130. 
Carbelo-Baquero, B., Alonso, M. C., Valero-Garces, C. \& Thorson, J. A. (2006). 'A study of sense of humor in Spanish and American samples'. North American Journal of Psychology 8(3), pp. 447-454.

Davies, C. (1990). Ethnic Humor Around the World: A Comparative Analysis. Bloomington: Indiana University Press.

Davies, C. (1998). Jokes and Their Relation to Society. Berlin: Mouton de Gruyter.

Davies, C. (2002). The Mirth of Nations. New Brunswick: Transaction Publishers.

Davies, C. (2011). Jokes and Targets. Bloomington \& Indianapolis: Indiana University Press.

Đergović-Joksimović, Z. (2015). Barbarogenius and utopia. Književna istorija 47(156), pp. 107119.

Fiske, S. T., Cuddy, A. C., Glick, P. \& Xu, J. (2002). 'A model of (often mixed) stereotype content: competence and warmth respectively follow from perceived status and competition'. Journal of Personality and Social Psychology 82(6), pp. 878-902.

Fiske S. T., Xu, J., Cuddy, A. C. \& Glick, P. (1999). '(Dis)respecting versus (dis)liking: status and interdependence predict ambivalent stereotypes of competence and warmth'. Journal of Social Issues 55(3), pp. 473-489.

Glick, P. \& Fiske, S. T. (1999). 'Sexism and other "isms:" Independence, status, and the ambivalent content of stereotypes', in Swann, W. B., Langlois, J. \& Gilbert, L. A. (eds.), Sexism and Stereotypes in Modern Society: The Gender Science of Janet Taylor Spence, Washington DC: American Psychological Association, pp. 193-221.

Heck, R. H., Thomas, S. L. \& Tabata, L. N. (2010). Multilevel and Longitudinal Modeling with IBM SPSS. New York: Routledge.

Hofstede, G. (1980). Culture's Consequences: International Differences in Work-related Values. Beverly-Hills, CA: Sage.

Hofstede, G. \& Bond, M. H. (1988). 'The Confucius connection: From cultural roots to economic growth'. Organizational Dynamics 16(4), pp. 5-21.

Hofstede, G. (2001). Culture's Consequences; comparing Values, Behaviors, Institutions, and Organizations across Nations. Second Edition. Thousand Oaks, CA: Sage.

Hofstede, G., Hofstede, G. J. \& Minkov, M. (2010). Cultures and Organization; Software of the Mind (revised and expanded third edition). New York: McGraw-Hill.

Hofstede, G. J. 2018. Humour Across Cultures: An Appetizer. Retrieved 21 June 2018 from https://pdfs.semanticscholar.org/4f2f/ddee5330cf8ac76a9171dafb30fb0388c4cf.pdf.

Hofstede, G.; Minkov, M. (2018). 'Value Survey Module 2013 Manual'. Retrieved 25 June 2018 from https://geerthofstede.com/research-and-vsm/vsm-2013/

Ho, S. K., Chik, M. P. Y. \& Thorson, J. A. (2008). 'Psychometric study of a Chinese version of the Multidimensional Sense of Humor Scale'. North American Journal of Psychology 10(2), pp. 425-434.

Inglehart, R. (1990). Culture Shift in Advanced Industrial Society. Princeton: Princeton University Press.

Inglis, V., Zach, S. \& Kaniel, S. (2014). 'Humor creator and the audience - A multi-dimensional model supported by in-vivo methodology'. American Journal of Educational Research 2(7), pp. 503-512.

Jontes, D. (2010). 'Slovenian sitcom and the construction of otherness'. Cultural Studies 24(5), pp. 716-728.

Kalliny, M.; Crutthirds, K. W. \& Minor, M. S. (2006). 'Differences between American, Egyptian and Lebanese humor styles: implications for international management'. International Journal of Cross Cultural Management 6(1): pp. 121-134.

Kazarian, S. S. \& Martin, R. A. (2006). 'Humor-styles, culture-related personality, well-being, and family adjustment among Armenians in Lebanon'. HUMOR: International Journal of Humor Research 29(4), pp. 405-423. 
Koncewicz-Dziduch, E. (2017). 'Commentary piece: Sociocultural characteristics of Montenegrins - the negative message in positive jokes'. The European Journal of Humour Research 5(2), pp. 71-79.

Kruger, J. \& Dunning, D. (1999). 'Unskilled and unaware of it: How difficulties in recognizing one's own incompetence lead to inflated self-assessments'. Journal of Personality and Social Psychology 77(6), pp. 1121-1134.

Kuiper, N. A., Kazarian, S. S., Sine, J. \& Bassil, M. (2010). 'The impact of humor in North American versus Middle East cultures'. Europe's Journal of Psychology 6(3), pp. 149-173.

Kuipers, G. (2015). Good Humor Bad Taste. A Sociology of the Joke. Berlin/Boston: Mouton de Gruyter.

Kuipers, G. \& van der Ent, B. (2016). 'The seriousness of ethnic jokes: Ethnic humor and social change in the Netherlands, 1995-2012'. HUMOR: International Journal of Humor Research 29(4), pp. 605-633.

Leach, C. W., Ellemers, N. \& Barreto, M. (2007). 'Group virtue: The importance of morality (vs. competence and sociability) in the positive evaluation of in-groups'. Journal of Personality and Social Psychology 93(2), pp. 234-249.

Lefcourt, H. \& Martin, R. A. (1986). Humor and Life Stress: Antidote to Adversity. New York: Springer/Verlag.

Lockyer, S. \& Pickering, M. (2008). 'You must be joking: The sociological critique of humour and comic media'. Sociology Compass 2(3), pp. 808-820.

Luketić, K. (2013). Balkan: od geografije do fantazije (The Balkans: from Geography to Fantasy). Zagreb, Mostar: Algoritam.

Lundquist, L. (2014). 'Danish humor in cross-cultural professional settings: linguistic and social aspects'. HUMOR: International Journal of Humor Research 27(1), pp. 141-163.

Marković, I. (2018). 'Croatian jokes about Bosnians'. Croatica 42(62), pp. 365-380.

Martin, R. A. \& Lefcourt, H. M. (1984). 'Situational Humor Response Questionnaire: Quantitative measure of sense of humor'. Journal of Personality and Social Psychology 47(1), pp. 145-155.

Martin, R. A., Puhlik-Doris, P., Larsen, G., Gray, J. \& Weir, K. (2003). 'Individual differences in uses of humor and their relation to psychological well-being: Development of the Humor Styles Questionnaire'. Journal of Research in Personality 37(1), pp. 48-75.

Martin, N. G. \& Sullivan, E. (2013). 'Sense of humor across cultures: A comparison of British, Australian and American Respondents'. North American Journal of Psychology 15(2), pp. 375-384.

Minkov, M. (2007). What Makes us Different and Similar: A New Interpretation of the World Values Survey and Other Cross-cultural Data. Sofia: Klasika i Stil.

Neff, P. \& Rucynski, J. (2017). 'Japanese perceptions of humor in the English language classroom'. HUMOR: International Journal of Humor Research 30(3), pp. 279-301.

Petrović, N. (2003). 'Međusobni stereotipi Hrvata, Bošnjaka i Srba u svetlu dvofaktorske teorije predrasuda' (Mutual stereotypes between Croats, Bosniaks and Serbes in light of the twofactor theory of prejudice). Sociologija 45(1), pp. 15-32.

Podrug, N., Filipović, D, Stančić, I. (2014). 'Analysis of cultural differences between Croatia, Brazil, Germany and Serbia'. Economic Research-Ekonomska istraživanja 27(1), pp. 818829.

Robinson, D. T. \& Smith-Lowin, L. (2001). 'Getting a laugh: Gender, status, and humor in task discussions'. Social Forces 80(1), pp. 123-158.

Ruch, W. \& Forabosco, G. (1996). 'A cross-cultural study of humor appreciation: Italy and Germany'. HUMOR: International Journal of Humor Research 9(1), pp. 1-18. 
Saroglou, V. \& Scariot, C. (2002). 'Humor styles questionnaire: personality and educational correlates in Belgian high schools and college students'. European Journal of Personality 16(1), pp. 43-54.

Skoko, B. (2010). Hrvatska i susjedi (Croatia and its Neighbors). Zagreb: AGM.

Skoko, B. (2012). Imidž Bosne i Hercegovine i njezinih građana u Hrvatskoj i Srbiji (Image of Bosnia and Herzegovina and its Citizens in Croatia and Serbia). Sarajevo: Friedrich Ebert Stiftung.

Slugan, M. (2011). Responses to Balkanism in Emir Kusturica's Život je čudo/Life is a Miracle (2004). Studies in Eastern European Cinema 2(1), pp. 37-47.

Sousa, L. M. M., Marques-Vieira, C. M. A., Severino, S. S. P., Pozo-Rosado, J. L., Antunes, A. V., José, H. M. G. (2018). 'Validation of the multidimensional sense of humor scale in people with chronic kidney disease'. Journal of Nursing Education and Practice 8(3), pp. 72-79.

Spaskovska, Lj. (2017). The Last Yugoslav Generation. The Rethinking of Youth Politics and Cultures in Late Socialism. Manchester: Manchester University Press.

Svebak, S. (1974). 'A theory of the sense of humor'. Scandinavian Journal of Psychology 15(1), pp. 99-107.

Svebak, S. (1996). 'The development of the Sense of Humor Questionnaire: From SHQ to SHQ6'. HUMOR: International Journal of Humor Research 9(3-4), pp. 341-361.

Svebak, S. (2010). 'The Sense of Humor Questionnaire: Conceptualization and review of 40 years of findings in empirical research'. Europe's Journal of Psychology 6(3), pp. 288-310.

Takovski, A. (2018). 'Extending ethnic humour theory: Genuine vs. functional ethnic joke scripts'. The European Journal of Humour Research 6(2), pp. 60-80.

Thorson, J. A. \& Powell, F. C. (1993a). 'Development and validation of a multidimensional sense of humor scale'. Journal of Clinical Psychology 49(1), pp. 13-23.

Thorson, J. A. \&. Powell, F. C. (1993b). 'Sense of humor and dimensions of personality'. Journal of Clinical Psychology 49(6), pp. 799-809.

Todorova, M. (2009). Imagining the Balkans (Updated Edition). Oxford: Oxford University Press.

Yue, X. D. (2010). 'Exploration of Chinese humor: historical review, empirical findings, and critical reflections'. HUMOR: International Journal of Humor Research 23(3), pp. 403420.

Yue, X. D. \& Hiranandani, N. A. (2014). 'Perception of humorists: a cross-cultural study of undergraduates in Hong Kong, Hangzhou, and Vancouver'. Comprehensive Psychology 19(3), pp. 1-5.

Yue, X. D., Yiang, F., Lu, S. \& Hiranandani, N. A. (2016). 'To be or not to be humorous? Cross cultural perspectives on humor'. Frontiers in Psychology 7(1495). Retrieved 14 January 2019 from http://dx.doi.org/10.3389/fpsyg.2016.01495.

West, R. (1946). Black Lamb and Grey Falcon. The Record of a Journey Through Yugoslavia in 1937. London: Macmillan \& Co. Ltd. 